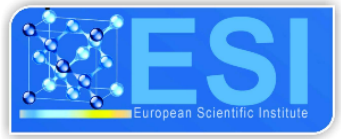

10 years ESJ

Special edition

\section{Bateh, Ph.D.}

Professor at the New York School of Management \& Technology \& Research Center for International Business

Submitted: 25 August 2020

Accepted: 07 September 2020

Published: 22 December 2020

Corresponding author:

D. Bateh

DOI: $10.19044 /$ esj.2020.v16n37p21

(c) Copyright 2020 Bateh, D.

Distributed under Creative Commons

BY-NC-ND 4.0 OPEN ACCESS

\section{Cite as:}

Bateh, D. (2020). The Entrepreneurial Lens Toward the 2030 Vision in Saudi Arabia: Jeddah's Contributions to Regional Growth. European Scientific Journal, ESJ, 16(37), 21. https://doi.org/10.19044/esj.2020.v16n37p21

\section{The Entrepreneurial Lens Toward The 2030 Vision in Saudi Arabia: Jeddah's Contributions to Regional Growth}

\begin{abstract}
The evolution of globalization, as many may refer to as "Westernization" can be measured differently from one part of the world to the next. The global mindset, which often includes a rise in entrepreneurship is one of the key markers toward growth within a nation. Countries that have much potential economically, such as Saudi Arabia, have fallen behind in economic development over the years in the area of entrepreneurship primarily due to the lack of early entrepreneurial education, policies, and culture. More recently, however, the country's 2030 vision has been the impetus for entrepreneurs to gain support through funding, policy changes, and support through the expansion of the country's entrepreneurial ecosystem. Jeddah, the largest port city in the Mecca (Hejaz) Region of Saudi Arabia, has taken the lead within the ecosystem, not only contributing to the growth of the country, but also to the regional economic development of the MENA region. The purpose of this research is to examine the policies, key players, and industries that lie within local entrepreneurship in Jeddah and its impact on regional economic development.
\end{abstract}

Keywords:

Entrepreneurship,

Ecosystem,

Reg 


\section{Introduction}

Regional economic development is marked by many economic indicators such as employment, education, GDP, consumer price index, foreign direct investment (FDI), and the like. As countries worked toward embracing the many aspects of globalization, entrepreneurship came to rise, contributing to self-employment, which added to the economic contributions to several regions of the world. Management practitioners have agreed that successful new ventures not only contribute to employment but also to political and social stability as well as innovation and competition (Khan, 2013; Thurik and Wennekers, 2004; Zedwitz, 2003; Hoffman et al, 1998, Dunkelberg, 1995). Although this new impetus in entrepreneurship grew rapidly in many nations, other nations lagged in grabbing onto the opportunity due to cultural norms, policies, and lack of the mindset needed to pursue such ventures. The aforementioned scenario was one that Saudi Arabia faced for many years, until more recently when the country established its 2030 Vision, which includes the support for development of new ventures that will thus, support not only the local economy but also contribute to the growth of the MENA region. This research sets forth the dynamics of entrepreneurship in Saudi Arabia, focusing on Jeddah, and the its contribution to the region.

\section{Scope of Entrepreneurship in Saudi Arabia - Focus on Jeddah}

One of the major port cities of Saudi Arabia, Jeddah, has led in the entrepreneurial movement. At the time of this writing, Jeddah, which is included in the data that contributes to the Mecca Region's Ecosystem, holds one of the highest-ranking positions for entrepreneurial development:

Mecca Region's Ecosystem

\begin{tabular}{|c|c|}
\hline CATEGORY & NUMBER \\
\hline Enterprises & 84 \\
\hline Mentors & 28 \\
\hline $\begin{array}{c}\text { Professional } \\
\text { Services }\end{array}$ & 31 \\
\hline $\begin{array}{c}\text { Support } \\
\text { Entities }\end{array}$ & 26 \\
\hline $\begin{array}{c}\text { Funding } \\
\text { Institutions }\end{array}$ & 5 \\
\hline $\begin{array}{c}\text { Volume of } \\
\text { Investment }\end{array}$ & $\mathbf{4 2 6 , 8 1 2 , 5 0 0}$ \\
\hline $\begin{array}{c}\text { Number of } \\
\text { Deals }\end{array}$ & 13 \\
\hline $\begin{array}{c}\text { Policy \& } \\
\text { Regulations }\end{array}$ & 27 \\
\hline $\begin{array}{c}\text { Entrepreneurial } \\
\text { Stories }\end{array}$ & 23 \\
\hline
\end{tabular}




\begin{tabular}{|c|c|}
\hline $\begin{array}{c}\text { Competitors \& } \\
\text { Awards }\end{array}$ & 15 \\
\hline Publications & 37 \\
\hline
\end{tabular}

Figure 1 (See Lab, n.d.)

New ventures lie within logistics, translation, tourism, fashion, food/beverage, and online tech services, to name a few. Within the ecosystem are supporting organizations within the major cities of Saudi Arabia: Riyadh - 54\%; Jeddah - 29\%; Eastern Province -10\%; and Makkah and Thuwal $-8 \%$ (Rahal, 2017).

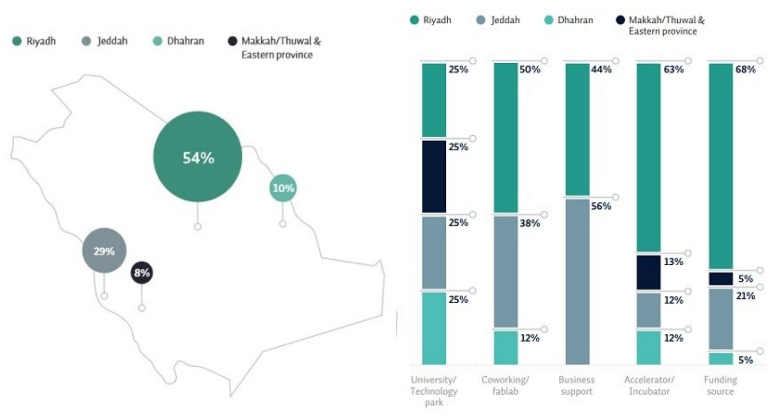

Distribution of support institutions by city.

Figure 2 (Rahal, 2017)

One may learn from Figure 2, that Jeddah holds second position in the ecosystem, and the local area continues to grow. What has contributed to this upward movement are the transformations within universities in Jeddah, offering entrepreneurship coaching, accelerator labs, and supporting business clubs. The King Abdullah University of Science and Technology (KAUST), for example, is one of the more developed universities, providing mentors, competitions, and start-up activities (Chowdhury, 2019). In addition, many Saudis have established co-working spaces, which have opened-up cost-effective and supportive opportunities for new and semiseasoned ventures. Other supporters that lie within the ecosystem in Jeddah are Startup Grind Jeddah, Flat6Labs Jeddah, and Badir Jeddah Incubator, just to name a few. Additionally, the Entrepreneurs' Organization, known as EO Saudi Arabia-Jeddah, represents one of the 61 countries local chapter for the global EO currently with 45 members, $\$ 3$ million in sales, and 21.083 employees (Entrepreneurs' Organization, 2020). Members have access to funding, mentors, and support in launching or developing their ventures.

The continual development of the region also includes the King Abdullah Economic City (KAEC), with branches located in Jeddah, Mecca, and Medina. Not only is KAEC set to lead in global trade, but also in 
strengthening the country's private and public partnerships, which include collaboration of Babson Global, a leader in Entrepreneurship Ecosystem Research (KAEC, n.d.). Additionally, the single regulator for the KAEC area the Economic Cities Authority, which presents easy access for licenses and permits for managing, owning, and operating businesses and also supports the 2030 Vision of the Kingdom (KAEC, n.d.). For Jeddah, this presents many opportunities as it is a port city, so new ventures that fall into the categories of logistics (where the area will also house manufacturing facilities), transportation and trade have great opportunities. Members stem from all industries and are able to gain access to resources, training, and managerial support and they launch and grow their ventures.

The competitiveness amongst of Saudi entrepreneurs is increasing as the demand for new ventures is growing. The Global Entrepreneurship Monitor (GEM) (2018) data supports this impetus, reporting twice as many entrepreneurs - $46 \%$ in 2018 versus $21 \%$ in 2016. Although men showed a higher rate of development than women, the motivational factor for women is primarily based on necessity ("More Saudis Develop", 2019). Women's participation in entrepreneurial activities will be further discussed in the subsequent section. Overall, Jeddah took the lead in 2018 Total Entrepreneurial Activity (TEA) reaching 23\%, as it is considered more up and comingin the field, while Riyadh is more established in its ecosystem ("More Saudis Develop", 2019).

Thus far, we have noted that Saudi Arabia has potential to continue growing its ecosystem. Education, mentors, financial resources, and the like, create a platform for the future development within the local regions within the Kingdom. Jeddah is now on a pathway for growth and has additional growth potential due to its proximity to the port. The potential also includes collaboration with both local and foreign participants that will allow the spread of new ideas, stemming from the Kingdom and strengthening its regional and global presence. Although no system is without challenges, policies and regulations such as those established in the KAEC are moving toward the support of new ventures, offering opportunity and ease of establishment - leading to a future that appears bright while the Kingdom moves toward its 2030 Vision. 
In Figure 3, we can see that Jeddah takes the lead in entrepreneurial activity $(\mathrm{TEA}=22.6 \%)$,

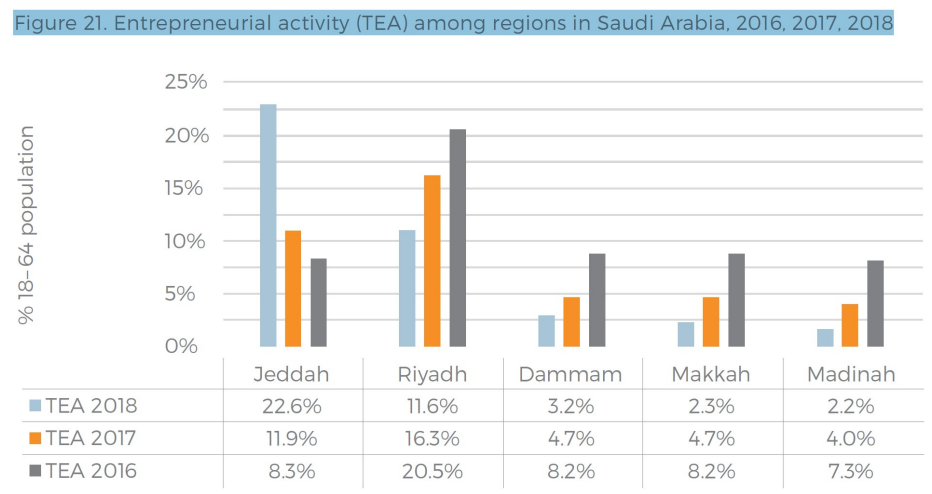

Figure 3 (GEM, 2019)

In order to better understand the composition of entrepreneurial ventures, it is important to learn more about the main contributors to the ecosystem. The segment that will be reviewed in the subsequent section is one that has evolved tremendously over the past few years, making strides and contributions to entrepreneurial development in Saudi Arabia. Thus, it is relevant not only to mention but to consider its impact in the future, the 2030 Vision, and to the MENA region as a whole.

\section{The Rise of Female Entrepreneurs}

In 2018 , only $41 \%$ of women/94\% males who had a post-secondary education were employed in Saudi Arabia (OECD, 2019). Although the percentage of women working was the lowest amongst the G20 nations that reported, male employment ranked one of the highest rates amongst the countries (OECD, 2019). This data may not seem positive for women in the country; however, the evolution of women is rapidly changing the outlook for them in the future. Common contributors of to the female entrepreneurial movement are unemployment and work-life imbalance (Alhothali, 2020; Walker, Wang, \& Redmond, 2008). This transformation may be linked to cultural norms, which often impacted women working outside of the home but are now changing the way in which they work, often through entrepreneurial activities. It is important to note that most Saudi female entrepreneurs have either a graduate or post-graduate degree (MinkusMcKenna, 2009). In fact, in 2017, Saudi women accounted for 30\% of the total number of entrepreneurs in the Kingdom, an increase of $35 \%$ since 2007 ("Saudi Females Increase", 2020). What has contributed to this growth is support from both the government and private sector, as they play 
a great role in the 2030 Vision. One such supporter is a portal - Women in Business Network - Monsha'at - aiming to increase women's participation in business (Saudi Women Entrepreneurs, 2018).

Although the support for women pursuing entrepreneurial ventures has greatly contributed to the rise in participation, there are other factors that have played a role in women participating in the ecosystem. Women still face the cultural obstacles when trying to enter the traditional workforce; however, they often pursue entrepreneurial ventures rather than waiting for a job opportunity (Khizindar and Darly, 2017). In fact, increasing female entrepreneurs has been a priority of the government (Bassafar, Niehm, \& Bosselman, 2018; Fallatah, 2012). This growth does not dismiss the cultural challenges within Saudi Arabia but also within the MENA region - concerns regarding lack of interest in marriage if women become actively involved in the workforce and after-hours activities that require their presence, and general the socialization that is required as an entrepreneur exist, to name a few. Additionally, looking toward the 2030 Vision, it is expected that many of these socio-cultural restrictions/obstacles will soon fade as the role of women is changing.

Women hold value within society, and as they pursue entrepreneurship, they are able to support economic growth and share their potential within the ecosystem. We learned that women who pursue entrepreneurship either have pursued higher education - indicating that more women are going to college rather than staying at home. The new resources in the country that support entrepreneurial education within universities allow women to benefit from this support while pursuing education. Figure 4 below supports our understanding the factors that influence the realization of Saudi women's entrepreneurship:

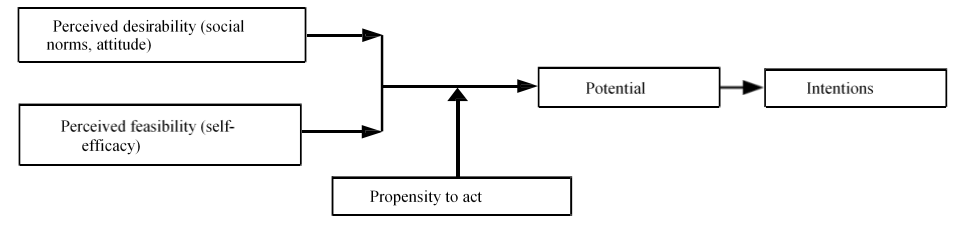

Figure 4. Krueger and Brazeal's MEP, simplified (1994)

Those who possess a high level of perceived efficacy are more likely to set challenging goals (Bassafar, Niehm, \& Bosselman, 2018); Bandura, 1990). Figure 5 displays a modified version of entrepreneurial women in Saudi Arabia: 


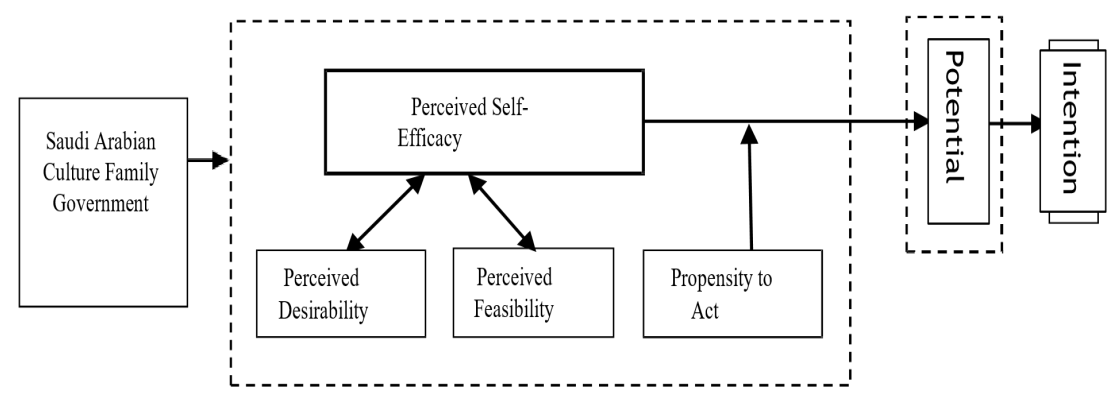

Figure 5 Modified Model of Entrepreneurial Potential for Saudi Arabian businessowning women. (Bassafar, Niehm, \& Bosselman, 2018)

In order to better understand the impact of education, self-efficacy, and industries that female entrepreneurs in Saudi Arabia support, we will reference a survey conducting in research by Bassafar, Niehm, \& Bosselman, (2018). Although a few numbers of Saudi female entrepreneurs responded to the study (9 out of 10), we can see the trend toward participating in the ecosystem and create assumptions for growth. Figure 6, below, offers the results of the survey:

Demographic survey results, business-owning Saudi women $(N 1 / 49)$. Interview Marital Status Years and Type of Business Number of Education ee Employees

\begin{tabular}{|c|c|c|c|c|}
\hline BW-1 & Divorced & $\begin{array}{l}18 \text { years: fashion, tailoring } \\
\text { and sewing; } 2 \text { years: } \\
\text { father's trade }\end{array}$ & $\begin{array}{l}\text { 8 females; } \\
\text { is director }\end{array}$ & $\begin{array}{l}\text {; son Master's degrees (Isla } \\
\text { studies, mental health) }\end{array}$ \\
\hline BW-2 & Single & $\begin{array}{l}14 \text { months: handcrafts and } \\
\text { ceramics }\end{array}$ & None & $\begin{array}{l}\text { Bachelor's degree Arabic } \\
\text { Studies }\end{array}$ \\
\hline BW-3 & Married & $\begin{array}{l}6 \text { or } 8 \text { years: home business } \\
2 \text { years: gifts and package- } \\
\text { ing shop }\end{array}$ & None & $\begin{array}{l}\text { Bachelor's degree in arts } \\
\text { and design }\end{array}$ \\
\hline BW-4 & Single & 1 year: cosmetics shop & None & $\begin{array}{l}\text { Bachelor's degree } \\
\text { in } \\
\text { biology }\end{array}$ \\
\hline BW-5 & Married & $\begin{array}{l}1 \text { year: working in bazaars } \\
15 \text { years: sewing shop }\end{array}$ & None & Middle school \\
\hline BW-6 & Married & $\begin{array}{l}22 \text { years: beauty and } \\
\text { chocolate shop }\end{array}$ & $\begin{array}{l}\text { 52-62 Saudis } \\
\text { and } \\
\text { Saudis }\end{array}$ & $\begin{array}{l}\text { Bachelor's degree } \\
\text { in } \\
\text { English studies }\end{array}$ \\
\hline BW-7 & Married & $\begin{array}{l}2 \text { years: photography } 3 \text { years: } \\
\text { Real estate office } 2 \text { years: }\end{array}$ & One & High school \\
\hline
\end{tabular}


Three interesting points to mention while framing and collecting data for the study that are worth mentioning:

1. When the researcher sought potential women-owned businesses through the Jeddah Chamber of Commerce \& Industry (established in 2008, supporting women in applying for business licenses) (Jeddah Chamber of Commerce, n.d.), it was realized that the many of the listed businesses owned by females were actually registered under the name of a male (Bassafar, Niehm, \& Bosselman, 2018).

For this point, we may hypothesize that although women may work in the listed business, they are actually owned by men. This could still be a cultural stigma within the society, but important to realize that data needs to be carefully analyzed in order to ensure female ownership.

2. Six of the women were over the age of 35 , while 3 were under the age of 35 - all selfemployed (Bassafar, Niehm, \& Bosselman, 2018).

We can learn that women seem to pursue entrepreneurship, most likely after marriage versus early on in life - college years, immediately after pursuing higher education.

3. The industries where women contributed most to the ecosystem are within creative areas: sewing/fashion, gifts/packaging, photography, etc.

From this small survey, we may assume that many women also pursue such industries as they may have been home for some time pursuing a hobby that now turned into an entrepreneurial venture. However, we should not dismiss that with the rise of female educational levels, we will see more females pursue tech ventures. This may be reinforced with the fact that 44 (and growing femaleowned tech participants were encouraged to enter the ecosystem by moving their tech ideas into new ventures, with the support of the Technology Incubator Program at Kind Abdul Aziz for Science and Technology (KAST) (“Saudi Women Are Taking Over", n.d.).

Overall, we may recognize that the role of women in society is everevolving, especially as we move closer toward the 2030 vision. It would not be surprising to see an increase in the rise of female-owned businesses over the next ten years, not only contributing to Saudi Arabia but to the MENA region as a whole. A change in the mindset is happening when it involves women - by empowering women, you change the family - thus making societal changes more feasible (Beggin, 2016). In fact, home based businesses have also increased in numbers. The table below demonstrates the characteristics of Home-Based Businesses in Jeddah, an area yet again, that has proven its place and marking its presence in the Saudi ecosystem: 
Figure 7 Frequency Distribution of socio-demographic variables and business characteristics

\begin{tabular}{|c|c|c|c|}
\hline Variables & Categories & Frequency & Percent \\
\hline Gender & Female & 34 & $100 \%$ \\
\hline \multirow[t]{6}{*}{ Business activity } & Fashion designing & 9 & $26.5 \%$ \\
\hline & Art and paintings & 3 & $8.8 \%$ \\
\hline & Handicrafts & 4 & $11.8 \%$ \\
\hline & Cooking & 13 & $38.2 \%$ \\
\hline & Women accessories & 4 & $11.8 \%$ \\
\hline & Sea related products & 1 & $2.9 \%$ \\
\hline \multirow[t]{3}{*}{ Education } & High school & 10 & $29.4 \%$ \\
\hline & Graduate & 22 & $64.7 \%$ \\
\hline & Post graduate & 2 & $5.9 \%$ \\
\hline \multirow[t]{6}{*}{ Age } & $15-18$ & 2 & $5.9 \%$ \\
\hline & $18-24$ & 1 & $2.9 \%$ \\
\hline & $25-34$ & 9 & $26.5 \%$ \\
\hline & $35-44$ & 16 & $47.1 \%$ \\
\hline & $45-54$ & 4 & $11.8 \%$ \\
\hline & 55 and more & 2 & $5.9 \%$ \\
\hline \multirow{5}{*}{$\begin{array}{c}\text { Management } \\
\text { experience }\end{array}$} & No experience & 16 & $47.1 \%$ \\
\hline & Less than a year & 3 & $8.8 \%$ \\
\hline & 1 to 5 years & 7 & $20.6 \%$ \\
\hline & 6 to 10 years & 5 & $14.7 \%$ \\
\hline & more than 10 & 3 & $8.8 \%$ \\
\hline \multirow{2}{*}{$\begin{array}{c}\text { Business } \\
\text { experience }\end{array}$} & Never owned a business & 31 & $91.2 \%$ \\
\hline & already owned a business & 3 & $8.8 \%$ \\
\hline \multirow{3}{*}{$\begin{array}{l}\text { Entrepreneurial } \\
\text { mode }\end{array}$} & starting up business & 34 & $100 \%$ \\
\hline & purchased the business & - & - \\
\hline & inherited the business & - & - \\
\hline \multicolumn{4}{|c|}{ Business Characteristics } \\
\hline \multirow[t]{5}{*}{ Age of Business } & Less than a year & 11 & $32.4 \%$ \\
\hline & 1 to 5 & 12 & $35.3 \%$ \\
\hline & 6 to 10 & 8 & $23.5 \%$ \\
\hline & 11 to 20 & 1 & $2.9 \%$ \\
\hline & More than 20 years & 2 & $5.9 \%$ \\
\hline \multirow[t]{5}{*}{ \# of employees } & No employees & 8 & $23.5 \%$ \\
\hline & 1 to 5 & 26 & $76.5 \%$ \\
\hline & 6 to 10 & - & - \\
\hline & 15 to 20 & - & - \\
\hline & More than 20 & - & - \\
\hline
\end{tabular}

(Alhotali, 2020)

Some highlights from this data is that $64.7 \%$ of female entrepreneurs had a graduate degree, and the age of most participants were between 35 and 44 years of age, which parallels some of the data in Figure 6, indicating that six out of nine female entrepreneurs surveyed was over the age of 35 . Additionally, the motivational factors that scored the highest amongst female entrepreneurs that own home-based businesses were support of friends and family, passion and love of what they want to pursue, and perceived convenience (Alhothali, 2020).

We now have had a glance at the areas in which women pursue entrepreneurship, only a portion of the contribution to the ecosystem. Now, we will delve into the primary growth sectors and opportunities for growth within the Kingdom. 


\section{Growth Opportunities}

In many countries, many innovations occur in high-technology industries; but this is not the case for Saudi Arabia (GEM, 2019). We may see the progression of tech/non-tech ventures within the Kingdom below in Figure 7: (\% TEA - Total Early-Stage Entrepreneurial Activity) (\% EB Established Business Ownership)

\begin{tabular}{|l|l|l|l|l|l|l|l|l|}
\hline $\begin{array}{l}\text { Technological } \\
\text { level }\end{array}$ & 2010 & 2016 & 2017 & 2018 & 2010 & 2016 & 2017 & 2018 \\
$\begin{array}{l}\text { None/low- } \\
\text { technology } \\
\text { sector }\end{array}$ & 98.5 & 99.2 & 98.5 & 97.7 & 97.3 & 100.0 & 97.3 & 97.6 \\
$\begin{array}{l}\text { Medium-or } \\
\text { high- } \\
\text { technology } \\
\text { sector }\end{array}$ & 1.5 & 0.8 & 1.5 & 2.3 & 2.7 & 0.0 & 2.7 & 2.4 \\
\hline
\end{tabular}

Figure 7 (GEM, 2019)

Tech, however, is not the only sector for growth within the ecosystem. Ventures across industries from food delivery to tourism applications are supported in preparation and in support of achieving the 2030 Vision Figure 8.

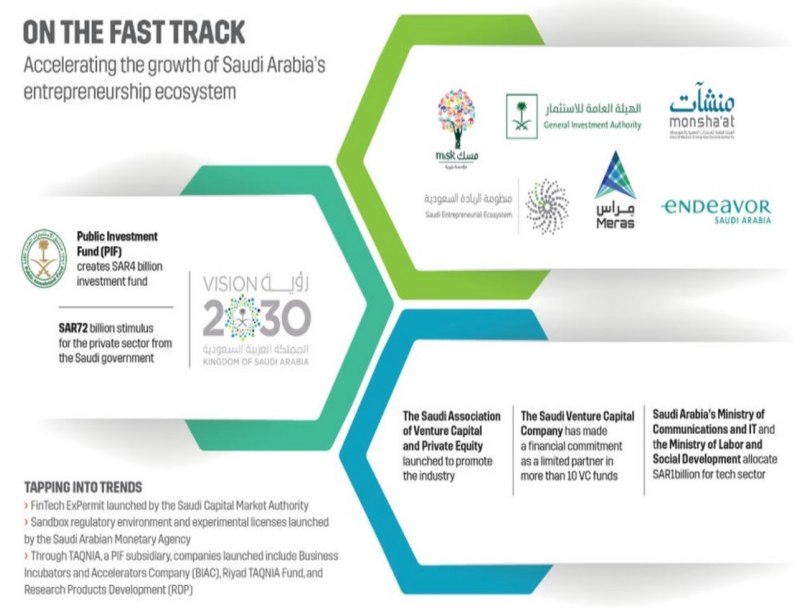

Figure 8 (Ashri, 2019)

New ventures are now are encouraged, especially for younger entrepreneurs through universities, governmental support, venture capitalists, culture, infrastructure are all components mandated for entrepreneurial growth in the Saudi 2030 Vision. The key to measuring growth will be to develop a more rigorous method in which to assess new venture exploration and activity, improved gaging of local entrepreneurship on the overall ecosystem, and the development of best practices among new ventures within specific 
industries. All of these factors and more will lead to the better understanding of entrepreneurship's contribution to the economy of Saudi Arabia but also to the MENA region.

A newly established agency, the National Entrepreneurship Content Index (NECI), established by the Global Entrepreneurship Monitor (GEM) assesses entrepreneurial potential within an economy, based on 12 framework conditions, which include entrepreneurial finance, government regulation and policies, and entrepreneurial education (Ashri, 2019). By having a more efficient way of measuring and learning the gaps and opportunities within a local market or region, one may better understand how to work toward economic development by improving upon what is working well and eliminating practices that contribute less to the growth and development of new ventures and strengthening the entrepreneurial mindset.

\section{Conclusion}

Throughout this research, we have discussed the entrepreneurial growth and development within Saudi Arabia, with a particular focus on Jeddah. Jeddah holds the leading position in entrepreneurial activity because of the potential contributions within the ecosystem and its size, and proximity to a port - thus, encouraging new ventures in the areas of logistics and manufacturing. The Saudi 2030 Vision also holds many of the guiding principles that support entrepreneurship within the local areas in the country that contribute to the overall economic development of the MENA region.

Although challenges still exist within the country - socio-cultural challenges, entrepreneurial education at early ages, and the establishment of best practices toward success of new and established ventures still exist. However, rather than focusing on the obstacles that hinder this ecosystem, the country has tried to break-through and to overcome the roadblocks within the region to encourage the societal potential, including but not limited to the support of female entrepreneurs, younger participants (in postsecondary education), and developing the entrepreneurial mindset at early ages.

Thus, the potential for Saudi Arabia and its key players in the ecosystem have the potential to transform the area at both local and regional levels. We not only have the potential to see increased economic growth and transformation within the local area but its impact on the MENA region. The future is bright for the Kingdom, and each year, as the country moves toward the 2030 Vision, we are likely to see a country that has had hidden opportunities, now emerge to bring opportunities within the country and to impact the region in a way in which we would not have imagined. As we culminate our knowledge from this research, it makes sense to end with a quote from MISK (2017), “This initiative, inspired by Vision 2030, will help 
Saudi Arabia attract the best minds in the world, transferring knowledge, expanding the economy, increasing the contribution of small- and mediumsized companies to GDP and creating jobs for Saudis." The best is yet to come.

\section{References:}

1. Alhothali, G. (2020). "Women entrepreneurs doing business from home: motivational factors of home-based business in Saudi Arabia", Adalya Journal, 9(1). Retrieved from https://adalyajournal.com/gallery/131jan-2662.pdf

2. Ashri, O. (2017, July 19). On the fast track - Saudi Arabia's entrepreneurial ecosystem. Retrieved from https://www.entrepreneur.com/article/336766

3. Bandura, A. (1990). Perceived self-efficacy in the exercise of personal agency, Applied Psychology 3, 128-63.

4. Bassafar, A., Niehm, L. and Bosselman, R. (2018). "Saudi Arabian women in entrepreneurship - challenges, opportunities, and potential", Journal of Developmental Entrepreneurship, 23(2). https://doi.org/10.1142/S1084946718500139.

5. Beggin, M. (2016, April 25). Tech and entrepreneurship - new avenues for female leadership in Saudi Arabia. Retrieved from https://www.nupoliticalreview.com/2016/04/25/tech-andentrepreneurshipnew-avenues-for-female-leadership-in-saudi-arabia/

6. Chowdhury, Naguib (2019, October 2). The Start-up vibes in Jeddah, Saudi Arabia, Retrieved from https://medium.com/predict/thestartup-vibes-in-jeddah-saudi-arabia-19b4395c161

7. Dunkelberg, W. (1995), "Presidential Address: Small Business and the US economy", Business Economics 30(1), 13-18.

8. Entrepreneurs' Organization (2020, August 12), EO Saudi Arabia Jeddah fact sheet. Retrieved from https://www.eonetwork.org/saudiarabiajeddah/about-our-chapter/

9. Fallatah, H. (2012). Women entrepreneurs in Saudi Arabia: investigating strategies used by successful Saudi women entrepreneurs (Master's Thesis), Lincoln University, New Zealand. Retrieved from https://researcharchive.lincoln.ac.nz/handle/10182/4795

10. GEM - Saudi Arabia (2019). Retrieved from https://www.gemconsortium.org/report/kingdom-of-saudi-arabiareport201819\#: :text=With\%20the\%20national\%20blueprint\%20of,we $\% 20$ have $\% 20$ yet $\% 20$ to $\% 20$ achieve.

11. Hoffman, K., Parejo, M., Bessant, J. and Perren, L. (1998), "Small firms, R\&D, technology and innovation in the UK: a literature review", Technovation, 18(1), 39-55. 
12. Jeddah Chamber of Commerce (n.d.). Retrieved from https://www.jcci.org.sa/English/Pages/default.aspx

13. Khan, M.R. (2013, March). "Mapping entrepreneurship ecosystem of Saudi Arabia", World Journal of entrepreneurship Management \& Sustainable Development, 9(1), 28-54. https://doi.org/10.1108/20425961311315700

14. Khinzidar, T. and Darley, W. (2017). "A study of female Middle Eastern entrepreneurs: a resource-based view", Journal of Research in Marketing and Entrepreneurship 19(1), 4258. https://doi.org/10.1108/JRME07-2016-0023

15. King Abdullah Economic City (KAEC), moving forward - a new world city for Saudi Arabia. Retrieved from https://www.kaec.net/wpcontent/uploads/2014/11/KAEC_CORPORATE_B ROCHURE-FINAL.pdf

16. Krueger, N.F. (1993). "The impact of prior entrepreneurial exposure on perception of new venture feasibility and desirability", Entrepreneurship Theory and Practice 18(1), 5-21.

17. Minkus-McKenna, D. (2009). "Women entrepreneurship in Riyadh, Saudi Arabia", University of Maryland University College, UMUC Working Paper Series- Number 2009-002, January 2009.

18. MISK (2017, November 15). Saudi Arabia opens its doors to overseas entrepreneurs. from https://miskglobalforum.com/saudi-arabia-opens-doors-overseasentrepreneurs/

19. "More Saudis develop an interest in becoming entrepreneurs" (2014, July 19). Retrieved from https://saudigazette.com.sa/article/571885

20. OECD, Employment at a glance - Saudi Arabia (2019). Retrieved from glance/EAG2019_CN_SAU.pdf

21. Rahal, Maya (2017, June 13). Big opportunities for startups in KSA [Report], Retrieved from https://www.wamda.com/2017/06/bigopportunities-startups-ksa-report.

22. Saudi Female entrepreneurs increase by $35 \%$ in 10 years: Report (2020, August 15). Retrieved from https://www.arabnews.com/node/1200291/saudi-arabia

23. Saudi women wre taking over the country's tech industry (n.d.). Retrieved from

24. https://www.abouther.com/node/8811/people/features/saudi-womenare-taking-overcountry $\% \mathrm{E} 2 \% 80 \% 99 \mathrm{~s}$-tech-industry

25. Saudi women entrepreneurs share expertise in innovation (2018, December 25). Retrieved from https://saudigazette.com.sa/article/551027 
26. See Lab (n.d.), Ecosystems activity in Mekkah. Retrieved from https://seelab.sa.com/en/community/activity/makkah

27. Thurik, R. and Wennekers, S. (2004), "Entrepreneurship, small business and economic growth",

28. Journal of Small Business and Enterprise Development 11(1), 140-9. Retrieved from https://pdfs.semanticscholar.org/475e/1c3712875a99adf17c8dcd18ec2279d5 fba7.pdf

29. Walker, E., Wang, C., \& Redmond, J. (2008). "Women and work life balance is home based business ownership the solution?" Equal Opportunities International 27(3), 258-275.

30. Zedtwitz, M. (2003), "Classification and management of ncubators: aligning strategic objectives and competitive scope for new business facilitation", International Journal of Entrepreneurship and Innovation Management 3(1), 176-96. 